\title{
Lokalność w krajobrazie. Etnograficzny przypis do projektu „Śladami Przeszłości po Gminie Mstów"
}

\author{
Locality in the Landscape. Ethnographic \\ Annotation to the Project "Śladami \\ Przeszłości po Gminie Mstów"
}

Impulsem do napisania tego tekstu stała się refleksja dotycząca tzw. lokalnej dobrej praktyki, którą etnograf wychwycił i zarejestrował w terenie ${ }^{\mathrm{r}}$. Tytułowy „przypis etnograficzny” dotyczy przedsięwzięcia zrealizowanego w 2015 r. w gminie Mstów (pow. częstochowski, woj. śląskie), polegającego na zainstalowaniu na terenie (w krajobrazie) tej jurajskiej gminy tablic informacyjnych pod wspólnym tytułem „Śladami Przeszłości po Gminie Mstów”. Tablice, prezentujące fotografie oraz krótką notatkę dotyczącą historii danego miejsca (dziś już często nieistniejącego lub posiadającego inny charakter), ustawione zostały w pierwotnych lokalizacjach obiektów odwołujących się do lokalnej historii i dziedzictwa. Pomysłodawcami projektu są gminni włodarze, współtwórcami zaś - co warto zaznaczyć - mieszkańcy. To oni nie tylko dzielili się wspomnieniami (stanowiącymi bazę do tworzenia opisów), ale przede wszystkim otwierali swoje domowe archiwa i udostępniali unikatowe, bo niedostępne w tzw. oficjalnych opracowaniach, fotografie.

Przedsięwzięcie wpisane w krajobraz gminy Mstów spełnia podstawowe warunki, które definiują szlak kulturowy, czyli:

I Tekst powstał na podstawie badań i z wykorzystaniem materiałów zebranych podczas realizacji projektu „Miejsca pamięci i zapomnienia. Badania interdyscyplinarne północnych terenów Jury Krakowsko-Częstochowskiej”. Projekt realizowany w ramach Narodowego Programu Rozwoju Humanistyki, w latach 2014-2019, na terenie 5 gmin powiatu częstochowskiego: Janów, Mstów, Lelów, Olsztyn, Przyrów. Więcej informacji na temat badań można znaleźć na oficjalnej stronie projektu: najurze.uni.lodz.pl. 
wytyczony i oznakowany szlak materialny, łączący obiekty i miejsca wybrane według ustalonego kryterium tematyzacji, będący unikatowym i reprezentatywnym przykładem ilustrującym szeroko pojęty dorobek kulturowy danego regionu, społeczności, grupy etnicznej, mniejszości narodowej czy narodu. Poprzez prezentację dziedzictwa materialnego szlak powinien umożliwiać poznanie i popularyzować dziedzictwo niematerialne, traktując oba te obszary jako nierozerwalną całość ${ }^{2}$.

Gminna ekspozycja terenowa przykuła moją - etnografa uwagę, dlatego, że oprócz zakładanych i posiadanych walorów krajoznawczych, edukacyjnych, służy ona pobudzeniu i zachowaniu pamięci o miejscach, których istnienie w społecznej świadomości i przypisywane im wartości pomagają podtrzymywać lokalną tożsamość. Ku dyskursowi wspólnoty, lokalnej społeczności mogą popłynąć zachęty do poszerzenia i pogłębienia wiedzy o miejscach na jej własnym terytorium, „odzyskania pamięci” i wprawienia w ruch praktyk narracyjnych. Impulsy te mogą sprawić, że miejsca niepamiętane, te więc, o których się nie wie, nie pamięta i nie opowiada, zostaną włączone w obszar żywej wiedzy, pamięci i opowieści.

Głównym pojęciem porządkującym i nadającym kontekst moim rozważaniom jest krajobraz rozumiany jako konstrukt kulturowy, społeczny oraz czasowy. Sięgam jedynie do wybranych, nielicznych spośród wielu idei; przede wszystkich tych, które kojarzą przestrzeń z pamięcią. Tworzę z nich klamrę otwierającą i zamykającą. Pomiędzy umieszczam opis przedsięwzięcia realizowanego w jurajskiej gminie. Zaproponowany etnograficzny przypis jest więc dodaniem do przykładu z terenu jednego z możliwych tropów analitycznych.

Pojęciem, które nie jest przeze mnie silnie eksploatowane, choć z pewnością mieści się w najbliższym kręgu odniesień, jest dziedzictwo kulturowe. Przemyka ono przez prowadzoną narrację dotyczącą krajobrazu i pojawia się tylko wtedy, gdy służy myśleniu o krajobrazie.

\section{KRAJOBRAZ (1) - natura/kultura, proces, dziedzictwo}

Krajobraz jest jakością heterogeniczną - przekonuje Tim Ingold, antropolog społeczny, od lat prowadzący na pograniczu kilku dyscyplin naukowych badania nad relacjami między człowiekiem a zamieszkiwanym przez niego środowiskiem. Próbuje on - oczywiście nie jako pierwszy - zbudować definicję krajobrazu. Jeden ze swoich tekstów rozpoczyna od wytłumaczenia,

2 Ł. Gaweł, Szlaki dziedzictwa kulturowego. Teoria i praktyka zarządzania, Kraków 2011 , s. 76. 
czym krajobraz nie jest. Powiada, że „krajobraz nie jest «ziemią», «naturą» czy «przestrzenią»"3. Ma swoją tożsamość, która wiąże się z innymi kategoriami, ale do nich się nie sprowadza i nie ogranicza. Jest czymś więcej niż fizyczną przestrzenią, określonym kartograficznie miejscem czy samą przyrodą - jest bardziej konstruktem symbolicznym aniżeli widokiem rzeczy; „światem znanym tym, którzy go zamieszkują, przebywają w jego miejscach i podróżują ścieżkami, które je łączą" ${ }^{4}$.

W tym znaczeniu krajobraz obejmuje to, co materialne i niematerialne, wiąże się ze środowiskiem i takimi dookreślającymi go pojęciami, jak: przestrzeń, miejsce, terytorium. Przynależy tak do kultury, jak i do natury. Beata Frydryczak - filozofka, ważna uczestniczka debaty dotyczącej rozumienia kategorii krajobrazu w naukach humanistycznych i społecznych - podkreśla, że natura jest tworzywem krajobrazu, kultura przydaje mu zaś sensów oraz wartości, wybrzmiewa w czasie znaczeniami i wyobrażeniami, które mają swoją społeczną podbudowę i są kształtowane historycznies.

Krajobraz jest więc procesem (wciąż aktualizowanym) przebiegającym w czasie: „postrzegać krajobraz oznacza sięgnąć w przeszłość, która go przeobraziła” - czytamy u T. Ingolda w tekście o „czasowości krajobrazu”. W tym procesie swój udział ma człowiek. Jest on w tej relacji nie tylko sprawcą, odbiorcą, uczestnikiem, ale także jednym z komponentów całości. „Krajobraz jest z nami, a nie naprzeciw nas” - to znów T. Ingold. „Ponieważ żyjemy w krajobrazie, staje się on częścią nas, tak jak my jesteśmy częścią jego"?.

Procesualność i czasowość krajobrazu to przymioty, które dają śmiałość, by pytać o związek z pamięcią, a także dziedzictwem kulturowym. David Lowenthal odpowiada tu wprost - „krajobraz jest podstawowym dziedzictwem każdego człowieka"s , które w formie zastanej otrzymujemy od poprzednich pokoleń i w postaci przez nas przetworzonej przekazujemy naszym następcom. Badacz jednoznacznie wskazuje rolę krajobrazu w kształtowaniu i podtrzymywaniu tożsamości kulturowej oraz społecznej.

3 T. Ingold, Czasowośćkrajobrazu, przeł. R. Chymkowski, [w:] Antropologia pamięci. Zagadnienia i wybór tekstów, red. P. Majewski, M. Napiórkowski, Warszawa 20ı8, s. 249.

4 Tamże, s. 250.

5 B. Frydryczak, Krajobraz: dziedzictwo zamieszkiwane, [w:] Dziedzictwo we wspótczesnym świecie. Kultura, natura, cztowiek, red. A. Marciniak, M. Pawleta, K. Kajda, Kraków 2018, s. 91. Zob. również: B. Frydryczak, Krajobraz. Od estetyki the pictuersque do doświadczenia topograficznego, Poznań 2013.

6 T. Ingold, dz. cyt., s. 25 I.

7 Tamże, s. 249.

8 D. Lowenthal, Życie z krajobrazem i oglądanie krajobrazu, przeł. D. Stadnik, [w:] Krajobrazy. Antologia tekstów, red. B. Frydryczak, Poznań 20I4, s. II I. 
Przy czym to, w jakim sensie i w jakim zakresie dziedziczymy krajobraz, a wraz z nim wpisane weń znaczenia i wartości, przynależy raczej do alinearnego czasu naturalnego, bliżej mu do pamięci i wspomnienia, z ich fragmentarycznością, zerwaniami ciągłości; niż do czasu historycznego, ciążącego ku uporządkowaniu i chronologii.

\section{GMINA - okolica, „tutaj”, „u nas”}

U T. Ingolda pojęcie krajobrazu spotyka się z pojęciem okolicy. Okolica to przestrzeń doświadczona, świat w postaci znanej, Heideggerowskie „miejsce epifanii bycia”. Zażyłość między człowiekiem a okolicą budowana jest w akcie oswajania tego, co obce, czynienia bliskim poprzez codzienne praktyki, ale także dzięki asystowaniu nieuniknionej zmianie. Okolica, a i krajobraz zatem, mają charakter wspólnotowy oraz lokalny, przynależą do tych, którzy - jak pisze B. Frydryczak - „tam mieszkali, mieszkają i będą mieszkać, zarazem do tych, którzy go w trakcie swojego życia kształtują"

Szerszy - większy, lecz ograniczony - fragment krajobrazu rozpatrywany z uwagi na osadzoną w jego ramach grupę (zbiorowość, społeczność) stanowi jej terytorium. Grupę dzięki zajmowanemu terytorium łączy zaś szczególna spójnia przemieniająca ją we wspólnotę terytorialną. To - jak pisał Stanisław Ossowski - „zespół ludzi, którzy zamieszkują wspólne terytorium i temu faktowi zawdzięczają w jakiś sposób swą więź społeczną" ${ }^{\prime \prime}$.

Przyjmijmy więc na użytek tekstu, ale jednocześnie z przekonaniem o słuszności tego założenia, że powyższe parametry spełnia gmina jako umowny fragment krajobrazu. Dlaczego „umowny”? Sięgam do rozważań Andrzeja Pawła Wejlanda:

Terytorium gminy jest ustalone administracyjnie - jego obecne granice nakładają się na granice z przeszłości, jego obecne centrum administracyjne może nie być centrum dawniejszym. Granice gminy umownie (a więc na swój sposób sztucznie) przylegają też do fizycznych i kulturowych właściwości krajobrazu. Krajobrazy gmin sąsiednich zazwyczaj przenikają się fizycznie i kulturowo, tu i tam są „porowate”, czyli "gąbczaste” - wchłaniają wzajemnie swoje właściwości, a ich peryferia, zwłaszcza odległe, mogą ciążyć ku innym ośrodkom gminnym. Sprzyja temu np. pozostawanie gmin sąsied-

9 H. Buczyńska-Garewicz, Miejsca, strony, okolice. Przyczynek do fenomenologii przestrzeni, Kraków 2006, s. 106

Io B. Frydryczak, dz. cyt., s. 95 .

II S. Ossowski, Dzieta, t. 3: Z zagadnień psychologii spotecznej, Warszawa 1967, s. 227. 
nich przez dłuższy okres w obrębie jednej, szerszej struktury administracyjnej - powiatowej lub wojewódzkiej, ale również działania na rzecz tworzonego przez nie (rzeczywistego lub wyobrażonego) regionu historycznego albo etnograficznego ${ }^{12}$.

Fakt, iż gmina jest umownym fragmentem krajobrazu, nie wyklucza tego, że wyraźnie wyodrębnia się ona w dyskursie wspólnotowym, na który składają się wszelkie sposoby odniesienia się wspólnoty jej wiedzą, pamięcią i opowieścią do własnego terytorium, czyli tego, z którym odczuwa ona „w jakiś sposób”, „jakąs’" więź. A.P. Wejland przekonuje, że owo doświadczanie własnego terytorium ma dwoisty charakter: na podłożu doświadczenia (poczucia) „tutaj”, czyli doświadczenia tutejszości (aspekt fizyczny krajobrazu) oraz na podłożu doświadczenia (poczucia) „u nas”, czyli doświadczenia swojskości (aspekt kulturowy krajobrazu) ${ }^{\text {r3 }}$.

W ujęciu kulturowym krajobraz konstytuuje się więc nie przez zwykłe zamieszkiwanie w danym miejscu, lecz taką formę obcowania z nim, która z miejsca czyni okolicę swojską i powiązaną z określonymi znaczeniami oraz wartościami. Przywoływany już T. Ingold przekonuje, że krajobraz składa się z miejsc bardziej i mniej znanych; przemierzanych, koncentrujących uwagę i tych pomijanych, bo już „opatrzonych”; stron przyjaznych i nieprzyjaznych. Łączy to, co indywidualne i zbiorowe, społeczne, kulturowe, historyczne i przyrodnicze; powiązane z pamięcią. To „przestrzeń zadana” (taskscape); praktykowana przez pracę i wszelką codzienną aktywność oraz konstytuowana przez zespół działań wspólnotowych, które przebiegają na przestrzeni dziejów i na gruncie których można mówić o kształtowaniu i stanowieniu krajobrazu ${ }^{14}$. Wnikliwa czytelniczka T. Ingolda - B. Frydryczak - podkreśla, że brytyjskiego antropologa interesuje „krajobraz jako miejsce styku przeszłości, teraźniejszości i przyszłości wyznaczone przez czas społeczny i określoną społeczność, która od pokoleń podejmuje wpisane w krajobraz «zadania »" "s. To one stanowią o tożsamości społeczności i określają jej dziedzictwo przekazywane pokoleniowo.

„Krajobraz zadany” - a nie krajobraz jako taki - istnieje dopóty, dopóki ludzie podejmują działania związane z byciem/działaniem/zamieszkiwaniem w konkretnym krajobrazie. Taką aktywnością - choć poszerzoną

\footnotetext{
I2 A.P. Wejland, Pojęcia podstawowe, [w:] Miejsca pamięci imiejsca zapomnienia. Interdyscyplinarne badania na Jurze Krakowsko-Częstochowskiej. Raportz badań, t. I: Wprowadzenie metodologiczne, red. A.P. Wejland, O. Ławrynowicz, Łódź 2016, s. 4I.

I3 Tamże.

I4 T. Ingold, dz. cyt., s. 252.

I5 B. Frydryczak, dz. cyt., s. 95.
} 
o kontekst pamięci, o czym za chwilę - jest w moim przekonaniu realizacja projektu „Śladami Przeszłości po Gminie Mstów”. Jego omówienie niech zostanie poprzedzone niekrótkim, choć bardzo wybiórczym wypisem z historii gminy. Zabieg ten być może wprowadzi ogólne ramy dla lokalnej historii przywoływanej w omawianym przedsięwzięciu.

Gmina Mstów (do I952 r. gmina Wancerzów) leży w północno-wschodniej części powiatu częstochowskiego, na terenie województwa śląskiego i zajmuje obszar ok. $120 \mathrm{~km}^{2}$. Pod względem administracyjnym tworzy ją I8 sołectw. Gmina znajduje się w ok. 60\% na obszarze Jurajskiego Parku Krajobrazowego bądź stanowi jego bezpośrednią otulinę. Charakterystycznymi elementami krajobrazu są tu wzgórza wapienne, malowniczy przełom rzeki Warty w okolicy Mstowa (stolicy gminy) oraz jabłoniowe sady, które od lat 30. XX w. lokowane są przede wszystkim w miejscowościach Zawada, Wancerzów i Siedlec ${ }^{16}$.

Procesy osadnicze na obszarze Wyżyny Częstochowskiej mają bardzo odległą, sięgającą paleolitu przeszłość. Źródła archeologiczne potwierdzają bytowanie na tych terenach ludności kultur pradziejowych, m.in. łużyckiej z epoki brązu (Gąszczyk nad Wartą w gminie Mstów). Od wczesnego średniowiecza osadnictwo zaczęło przemieszczać się na wysoczyzny, pod uprawę wykorzystywano również przestrzeń międzydolinnąa ${ }^{17}$.

W średniowieczu biegł tędy ważny trakt handlowy ze Śląska do Wielkopolski. Przez wieki region, leżąc na pograniczu Małopolski i Śląska, rozwijał się w oparciu o rzemiosło i handel. Nad brzegami Warty działały komory celne, regularnie organizowano targi. Nowy szlak wymagał odpowiedniego zabezpieczenia. Zaczęto więc już w XII w. budować wzdłuż jego trasy, początkowo drewniane, a następnie murowane strażnice obserwacyjne i zamki. Owocem tej nowej polityki była fundacja na ruinach starego kościółka nowego warownego klasztoru. W drugiej połowie XII w. w Mstowie osiedlili się kanonicy regularni opactwa Najświętszej Maryi Panny na Piasku we Wrocławiu, tworząc klasztor Kanoników Regularnych Laterańskich - jeden z najstarszych ośrodków życia zakonnego w Polsce. Dzieje tych terenów do początku wieku XIX były więc ściśle związane z klasztorem, a Mstów, za sprawą cudownego wizerunku Matki Bożej, umieszczonego w kościele

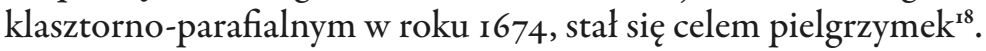

Był to w dziejach Mstowa i okolic moment zwrotny. W XIII w. Mstów otrzymał prawa miasta rządowego i na ówczesne czasy stanowił dużą siłą ekono-

I6 Więcej informacji na oficjalnej stronie internetowej gminy Mstów: http://www.mstow.pl/.

I7 M. Głowacki, J. Kopacz,Z Zradziejów regionu częstochowskiego, „Ziemia Częstochowska” 1974, t. Io, s. 47-56.

I8 Zob. więcej: Mstów. Miasto - klasztor-parafia na przestrzeni wieków, red. K. Łatak, Łomianki 2013. 
miczną słynącą głównie z produkcji doskonałejjakości wełny orazjejwyrobów. Funkcjonowały tu również cechy garncarzy, kowali, rzeźników i ślusarzy ${ }^{19}$.

W okresie Rzeczpospolitej Obojga Narodów opisywany obszar znalazt się w pasie szerokiego pogranicza polsko-austriackiego i polsko-pruskiego (do 1742 r.), co w aspekcie etnicznokulturowym przynosiło różnorodne kontakty oraz wpływy śląskie, czeskie, niemieckie.

Tereny te wielokrotnie, zwłaszcza w wiekach XVII i XVIII, doznawały zniszczeń związanych z toczącymi się w kraju wojnami, przemarszami wojsk, trapione były przez częste klęski żywiołowe - pożary, powodzie i dziesiątkujące mieszkańców zarazy ${ }^{20}$.

Drugi rozbiór Polski podzielił północną Jurę między dwa państwa zaborcze. Część na prawym brzegu Warty znalazła się w zaborze rosyjskim, natomiast lewobrzeżna - w zaborze pruskim.

Na początku XIX w. tereny dzisiejszej gminy Mstów próbowały jeszcze podźwignąć się z upadku, powstały manufaktury sukiennicze i bawełniane wytwarzające grube sukno, zbudowano kaflarnie, rozwinęło się szewstwo ${ }^{21}$. Dużą rolę w lokalnej społeczności i handlu zaczęli odgrywać Żydzi, którzy w Mstowie osiedlali się od końca XVIII w. Kryzys lat 40. XIX stulecia zniszczył jednak po raz kolejny rzemiosło produkcyjne, powodując powrót „chudych lat”. Następstwem tego stała się szybka agraryzacja. Mieszkańcy zaczęli także szukać lepszego życia w Częstochowie, zatrudniając się w tworzącym się tam wówczas przemyśle.

W czasie I wojny światowej odbywały się w okolicach pozycyjne walki artyleryjskie wojsk niemieckich i rosyjskich; tereny zostały wówczas przylączone do powiatu radomszczańskiego ${ }^{22}$.

W czasie II wojny światowej ludność okoliczna poniosła poważne straty. Zniszczono obiekty o historycznych walorach, na początku 1942 r. społeczność żydowską wysiedlono do getta w Radomsku. W końcowej fazie okupacji Mstów i okolicę włączono w linię umocnień mających zagrodzić drogę wojskom radzieckim podążającym do Częstochowy. Wybudowano bunkry, okopy strzeleckie i rowy przeciwczołgowe. W pobliżu zespołu klasztornego ulokowano lotnisko wojskowe ${ }^{23}$.

I9 Zob. więcej: J. Laberschek, Średniowieczne dzieje nadwarciańskiego Mstowa, Kraków 2014.

20 A. Sochnacki, Mstów w czasach staropolskich, [w:] Mstów. Miasto - klasztor - parafia na przestrzeni wieków, red. K. Łatak, Łomianki 2013, s. 17-29.

2 I A. Kubicki, Z przesztości Mstowa. Notatki kronikarskie od średniowiecza do I939 roku, Częstochowa 2011 .

22 Zob. więcej: K. Orman, P. Orman, Wielka Wojna na Jurze. Dziatania i cmentarze wojenne z roku IgI4 na Wyżynie Krakowsko-Wieluńskiej i terenach przylegtych, Kraków 2015.

23 J. Pietrzykowski, Hitlerowcy w powiecie czestochowskim 1939-1945, Katowice 1972. 
Po wojnie rozebrano szczątki spalonej synagogi. Na miejscu kościoła św. Stanisława, wzniesionego w XV w. na prawym brzegu rzeki Warty, wybudowano mleczarnię. Przez teren jednego z kilku cmentarzy cholerycznych poprowadzono drogę do nowego osiedla.

W przewodniku po gminie Mstów zachwalane są dzisiaj przede wszystkim krajobrazy Jury Krakowsko-Częstochowskiej, prezentowane są różne oferty aktywnego wypoczynku (spływy kajakowe, nordicwalking, wędkarstwo) oraz informacje o plenerowych imprezach lokalnych (m.in. Owocowo w Mstowie, Święto Kwitnącej Jabłoni, Święto Jabłka - wydarzenia akcentujące fakt, iż gmina jest „zagłębiem jabłkowym” w regionie) ${ }^{24}$.

W „Strategii Rozwoju Gminy Mstów” podkreślana jest zaś funkcjonalna i strategiczna przynależność do obszaru satelickiego miasta Częstochowy. $\mathrm{Na}$ gminę działają nieuchronne siły procesu urbanizacji. Zmienia się krajobraz - modyfikowany jest dotychczasowy ład przestrzenny, rozbudowywana jest infrastruktura, powstają nowe ulice, które prowadzą do nowych domów nowych mieszkańców, często realizujących swoje życie zawodowe w coraz bliższej Częstochowie ${ }^{25}$.

\section{„Śladami Przeszłości po Gminie Mstów"}

W 2015 r. gmina Mstów rozpoczęła realizację projektu „Śladami Przeszłości po Gminie Mstów”. Władze gminy we współpracy z Gminnym Ośrodkiem Kultury zorganizowały otwartą zbiórkę archiwalnych fotografii. Zaproszenie skierowane zostało do mieszkańców gminy, o pomoc poproszono lokalnych historyków i regionalistów. Zgromadzono potężny zbiór zdjęć, także tych, które do tej pory funkcjonowały tylko w prywatnych, domowych archiwach. Autorzy projektu zadbali o to, by ich właściciele - oprócz użyczenia fotografii - dzielili się także wspomnieniami, które zdjęć tych dotyczą.

Do tej pory zamontowano 25 tablic, na których prezentowane są miejsca w krajobrazie gminy. Ich wybór nie był z góry ustalony. Decydowały pozyskiwane $\mathrm{w}$ trakcie zbiórki materiały, a zatem na szlaku oznaczone są te miejsce, które niejako zgłosili mieszkańcy gminy. Scenariusz przedsięwzięcia zbudowany jest na prostym i czytelnym schemacie. Każda tablica poświęcona jest jednemu miejscu, zawiera tytuł, czyli nazwę własną miejsca,

24 Otwarta gmina Mstów. Przewodnik turystyczny, red. J. Pleszyniak, Katowice 2020 [dostęp: 2 czerwca 2020]. Dostępny w internecie: http://www.mstow.pl/media/2020/news-03/Przewodnik-turystyczny_Gmina-Mstow.pdf.

25 Na temat dynamiki przemian krajobrazu wsi Mstów zob.: A. Krupa-Ławrynowicz, Zmiany inapięcia w krajobrazie jurajskiej wsi. Na marginesie badań w Mstowie, „Zeszyty Wiejskie” 2016, t. 22, s. $153-167$. 
krótki opis dotyczący historii (poza kilkoma wyjątkami) oraz archiwalne fotografie. Niestety teksty zawarte na tablicach nie czerpią wprost z biograficznych narracji, z którymi do Urzędu Gminy zgłaszali się mieszkańcy. Zawierają ich przetworzoną, informacyjną wersję, wskazującą na lokalizację lub przeznaczenie obiektów.

Istotne, że tablice ustawiane są in situ lub - jeśli nie ma pewności lub możliwości - w miejscu najbliższym. Dzisiaj te pierwotne lokalizacje obiektów często mają zupełnie inny wygląd, pełnią inną funkcję - są np. poboczem kiedyś niepoprowadzonej jeszcze drogi, stoją na prywatnej, niedawno zbudowanej posesji. Zmiana formy i kontekstu dotyczy też prezentowanych na szlaku miejsc, których biografia za każdym razem odsłania swą palimpsestową strukturę. Wiele z nich nie tylko zmieniło charakter, ale po prostu przestało istnieć. Nie ma już synagogi w Mstowie, nie ma kościółka św. Stanisława. Zespół pałacowo-parkowy w Kłobukowicach - należący kiedyś do światowej sławy śpiewaków operowych (Jana i Edwarda Reszków) - na który składał się neogotycki pałac z drugiej poł. XIX w., XVIII-wieczny spichlerz, budynki folwarczne i ro-hektarowy park, po wojnie pełnił funkcję domu dziecka, był wielokrotnie przebudowywany, a dziś jest własnością prywatną. Po zabudowaniach dworu w Wancerzowie trudno odnaleźć ślady, to teraz tereny rekreacyjne. $\mathrm{O}$ cmentarzach cholerycznych również dowiadujemy się z tablicy. Krajobraz na nie nie wskazuje. Jedynym znakiem dla oka jest drewniany krzyż w lesie, na lekkim wzniesieniu.

Tablice oznaczają też miejsca, w których kiedyś, ale i wciąż, toczy się codzienne życie mieszkańców gminy - rynek w Mstowie, mstowskie ulice: Partyzancka, Ogrodowa, dawna Małuska. Przy okazji dowiadujemy się, gdzie znajdowała się kaflarnia, a gdzie rzeźnia. Fotografie odnotowują dynamikę przemian lokalnego krajobrazu. Pokazują „Stare Krasice”, „Stary Jaskrów”, „Stare chałupy w Małusach Małych”. Niektóre tablice dedykowane są wprost członkom lokalnej społeczności - np. Ochotniczym Strażom Pożarnym w Mstowie, Jaskrowie i Mokrzeszy. Czasem informacja nie zawiera opisu, ogranicza się jedynie do fotografii. Tak jest w przypadku Skały Miłości i Góry Wał - miejsc w krajobrazie, w których „od zawsze” spędzało się wolny czas, odpoczywało i pozowało do pamiątkowych zdjęć.

Jedynym wyjątkiem, który - z racji na swe datowanie - nie odwołuje się wprost do lokalnej pamięci dziedziczonej czy dzielonej, jest tablica poświęcona grodzisku Gąszczyk w Siedlcu. Zgodnie z archeologicznymi ustaleniami, stwierdzono tu pozostałości po osadzie pradziejowej kultury łużyckiej (lata 800-500 p.n.e.) oraz po grodzisku wczesnośredniowiecznym z IX-X w. Obecność tego obiektu na jurajskim szlaku łatwo jednak pojąć, gdy uznamy jego historyczną wartość, w pewien sposób nobilitującą współczesnych. 
Projekt ma formułę otwartą - włodarze gminy gotowi są rozbudowywać szlak. Każda z tablic opatrzona jest informacją: „Apelujemy o dostarczanie zdjęć, dokumentów, rysunków, map pokazujących miejsca, sytuacje, ludzi z terenu naszej gminy. Razem tworzymy archiwum o naszej wspólnej historii!”. Poniżej podane są dane kontaktowe kierujące do Urzędu Gminy Mstów. Tomasz Gęsiarz - wójt, w jednym z wywiadów zachęca:

Jesteśmy gotowi go rozwijać, dysponując dostateczną liczbą zdjęć z najprostszymi nawet opisami - zwłaszcza co do miejsc, osób i dat. Czasami warto spojrzeć, co jest w tle osób stojących na pierwszym planie, bo miejsca te dziś wyglądają zupełnie inaczej. Będziemy bardzo wdzięczni za użyczenie takich materiałów celem zeskanowania do wersji elektronicznej, bo oryginały oczywiście zwrócimy ${ }^{26}$.

\section{KRAJOBRAZ (2) - miejsca, pamięć, ślady}

Miejsca w krajobrazie, na terytorium zajmowanym przez lokalną społeczność, wspólnotę, stają się zwykle przedmiotem wspólnotowego dyskursu. Jedną z jego zasad staje się wtedy reguła odsiewu miejsc ważnych od nieważnych, np. miejsc, o których warto lub należy wiedzieć i pamiętać, a także opowiadać, i miejsc, które wiedza, pamięć i opowieść mogą pominąć. Za miejsca ważne wspólnota w dyskursie uznaje zapewne miejsca istotne, zasadnicze i rozstrzygające dla jej lokalnej tożsamości - wspominanego już w tym tekście poczucia tutejszości i swojskości. Do tego zasobu - jak się wydaje - sięgają autorzy szlaku w gminie Mstów.

Od Paula Connertona pochodzi użyteczne rozróżnienie dwóch typów miejsc ważnych:

- miejsca pamiątki (memorials lub memorial places) to miejsca odwołujące się do przeszłości gotowymi, społecznie wypracowanymi narracjami (które równie często objawiają, co zasłaniają historię), społecznie "mocne” także przez to, że mają swoje społecznie rozpowszechnione i ugruntowane nazwy;

- miejsca wyjątki (loci) to miejsca niemające utartych formuł opisu i opowiadania, sięgające raczej w narracjach do codziennego doświadczenia i intymnego życia, do „rzeczy zwykłych”, chociaż na swój sposób wyjątkowych, takich, dla których nie ma gotowych, raz na zawsze przypisanych nazw ${ }^{27}$. Dla badacza krajobrazu, ale także dla etnografa w terenie, szczególnie interesujące mogą być miejsca wyjątki. Pamięć typu locus dotyczy w głównej

\footnotetext{
26 Śladami Przesztości po Gminie Mstów, [dostęp: 2 czerwca 2020]. Dostępny w internecie: http:// www.mstow.pl/art/3939,sladami-przeszlosci-po-gminie-mstow.

27 P. Connerton, How Modernity Forgets, Cambridge-New York 2009, s. 7-39.
} 
mierze osób zamieszkujących dane terytorium, doświadczających je; wiąże się z bezpośrednią formą obcowania z tym, co zachował czas i pozostawił we wspomnieniu, a może tylko i aż w nawykach oraz gestach, „w których zachowujemy wersje przeszłości, przedstawiając je sobie w słowach i obrazach" ${ }^{28}$.

Miejsca wyjątki często nie mają gotowego „adresu”, trafi do nich ten, kto o nich wie, pamięta i opowiada. To odróżnia je od miejsc pamiątek - zwykle znaleźć można bowiem sporo wskazówek - tabliczek informacyjnych, drogowskazów, strzałek ku nim kierujących.

Każdemu z dwóch typów miejsc ważnych odpowiadają - jako dominujące - dwie różne praktyki związane z trwaniem i podtrzymywaniem wspólnotowej pamięci. Dla miejsc pamiątek charakterystyczna jest praktyka przypominania. Praktyka ta polega przede wszystkim na kreacji podniosłych wydarzeń mających oficjalnie upamiętnić (często przypomnieć poprzez aktualizujące przywołanie) dawne wydarzenia, również związane z nimi osoby. Poczucie trwania wymaga przecież pamięci i upamiętniania. Upamiętnianie dokonuje się zaś najczęściej poprzez rytuały i ceremonie symbolizujące osoby, miejsca i wydarzenia zbiorowej przeszłości ${ }^{29}$.

Miejsca wyjątki są natomiast objęte praktyką wspominania. Wspomina się je - myśli o nich i opowiada - zwykle „przy okazji” rozmaitych mało oficjalnych wydarzeń rodzinnych, codziennych spotkań przy stole, spaceru ze znajomymi po okolicy. Narracje im poświęcone rzadko bywają przygotowanymi przemowami in memoriam.

Wśród miejsc wybranych do zaprezentowania na szlaku w gminie Mstów dominują miejsca wyjątki, chciałoby się powiedzieć - miejsca „nieoczywiste”, o których informacji nie dostarczają łatwo dostępne i „niebudzące wątpliwości” opisy w przewodnikach turystycznych czy opracowaniach historycznych. Most na Warcie, plac, na którym przed wojną odbywał się targ, stodoły, wolnostojące piwnice, które służyły mieszkańcom do przechowywania pożywienia i zbiorów... Epizody z życia, które toczyło się niejako poza wielką, oficjalną historią, a jeśli w jej nurcie, to tylko wtedy, gdy wpływała ona na codzienność lokalnej społeczności (np. bunkry z czasów II wojny światowej). Kilka tablic poświęconych jest obiektom, którym łatwo przypisać wartość, nazwijmy ją - zabytkową lub historyczną (np. nieistniejący kościół wzniesiony w XV w., klasztor, dwory i folwarki). I one jednak w jakiś sposób tworzą lokalność, wpisują się w doświadczenie tutejszości oraz swojskości.

28 P. Connerton, Jak spoteczeństwa pamiętaja, przeł. M. Napiórkowski, Warszawa 20I2, s. I45.

29 Zob. P. Nora, Między pamięcią i historią: Leslieux de Mémoire, „Tytuł roboczy: Archiwum” 2009, nr 2; A. Szpociński, Miejsca pamięci (lieux de memoire), „Teksty Drugie” 2008, nr 4. 
„Ważność" miejsc pokazanych i opisanych na gminnych tablicach odwołuje się do różnych „wartości”. Spróbujmy to przedstawić, inspirując się myślą S. Ossowskiego:

- miejsca pamiątki ogniskują dyskurs wokół wartości uroczystych, ich ważność jest oparta na wartościach nadających dyskursowi charakter publiczny (tych w omawianym projekcie jest mniej);

- miejsca wyjątki ogniskują dyskurs wokół wartości codziennych, ich ważność znajduje podstawę w wartościach nadających dyskursowi charakter prywatny $^{3 \circ}$ (te na szlaku dominują).

Przydatne w analizie dyskursu dotyczącego miejsc ważnych w krajobrazie gminy może być jeszcze zwrócenie uwagi na inne, sięgające do doświadczenia wspólnoty skojarzenie:

- fragment krajobrazu z miejscami pamiątkami odnosi się do jego odczuwania (przeżywania) jako małej, lokalnej ojczyzny „ideologicznej”;

- fragment krajobrazu z miejscami wyjątkami wskazuje na jego odczuwanie (przeżywanie) jako małej, lokalnej ojczyzny „prywatnej”.

W obu wypadkach skojarzenie to interpretacyjnie rozciąga ustalenia S. Ossowskiego $0^{31}$, proponując użycie słowa „ojczyzna” za każdym razem „w sensie lokalnym". Jak przekonuje A.P. Wejland:

Dyskurs dotyczący małej, lokalnej ojczyzny „ideologicznej” dopuszcza mówienie o patriotyzmie lokalnym (np. gminnym) i - niosąc tony moralne - o przywiązaniu do lokalnej kultury i lokalnego dziedzictwa społecznego. Dyskurs odnoszący się do małej, lokalnej ojczyzny „prywatnej” akcentuje uczuciowy związek z nią poprzez urodzenie, spędzone lata dzieciństwa czy zamieszkanie (np. dla jej piękna) $)^{32}$.

$\mathrm{Na}$ jurajskim szlaku realizują się niejako socjologiczne koncepcje wspólnoty lokalnej i terytorialnej, ale także „wspólnoty wytworzonej”, o której pisze Dorota Angutek ${ }^{33}$ - posiadającej zarówno cechy stowarzyszenia, jak i wspólnoty w ujęciu Ferdinanda Tönniesa. D. Angutek przekonuje, że każda grupa lokalna, dla potwierdzenia swej tożsamości i wzmocnienia integracji, wymaga co pewien czas „akcji społecznych ożywiających i uświadamiających afiliacyjne cechy regionalne" ${ }^{34}$. Wytwarzane $w$ ten

\footnotetext{
30 S. Ossowski, Z zagadnień psychologii spotecznej, Warszawa 2000, s. 89-98.

3I S. Ossowski, O ojczyźnie i narodzie, Warszawa, s. 15-46.

32 A.P. Wejland, dz. cyt., s. 44-45.

33 D. Angutek, Tradycje wytworzone rodzącej sięponowoczesności w Polsce, Bydgoszcz 2018.

34 Tamże, s. 259.
} 
sposób tradycje i praktyki społeczne są odpowiedzią „podmiotów kultury na utratę symbolicznego jej wymiaru w rodzącej się epoce ponowoczesności, są wołaniem o przywrócenie przeżycia opartego na symbolach wspólnotowych" ${ }^{35}$. Zdaniem badaczki, "grupy wytworzone” czerpią inspiracje i motywację do działania z więzi lokalnych, małoojczyźnianych, opartych na wspólnotach w wąskim rozumieniu ${ }^{36}$. Przedsięwzięcie realizowane w gminie Mstów - powołane przez lokalnych liderów, o których roli wspomina w swojej koncepcji D. Angutek - ma więc tylko pozornie łatwe zadanie do spełnienia. Jest nie tylko atrakcją turystyczną, potwierdzeniem lokalnej operatywności, inwestycją w gminny wizerunek, może też chęcią dotrzymania kroku innym, podobnym realizacjom (coraz częściej widywanym w polskim krajobrazie), ale także wyrazem potrzeby wspólnoty.

Opisywane „ważność” i „wartości” odnaleźć można w krajobrazie, jeśli tylko damy się przekonać, że krajobraz ma charakter narracyjny: opowiada historię tych, którzy go ukształtowali i nadal kształtują, którzy byli i są jego częścią. Bo jak powiada Christopher Tilley:

Miejsca przypominają opowieści z nimi związane, a istnieją (jako lokalności noszące konkretne nazwy) wyłącznie dzięki swojej obecności w narracji. Miejsca, niczym ludzie, o tyle mają swoje biografie, o ile kształtowane są, używane i transformowane w powiązaniu z praktyką. Można założyć, że opowieści nabierają mitycznej wartości i historycznej wagi, kiedy zakorzenione są w konkretnych detalach lokalności krajobrazu i tym sposobem zyskują materialne punkty odniesienia, które można odwiedzić, obejrzeć i dotknąćc ${ }^{37}$.

Gminny szlak, którym w tym tekście podążamy, opowiada więc lokalną historię, sięga po lokalną pamięć - biograficzną, współdzieloną i dziedziczoną.

Krajobraz ma jeszcze jedną właściwość, która uwidacznia się w opisywanym jurajskim przedsięwzięciu - „przejmuje rolę medium pamięci i inwentaryzatora śladów" ${ }^{38}$. B. Frydryczak przekonuje, że ,niepamięć dotyka

35 Tamże, s. I2.

36 Tamże, s. 259.

37 Ch. Tilley, Praktykowaniekrajobrazu, przeł. D. Stadnik, [w:] Krajobrazy. Antologia tekstów, red. B. Frydryczak, Poznań 2014, s. 26.

38 B. Frydryczak, dz. cyt., s. ıoo. Przychodzą tu na myśl rozważania Aleidy Assmann, która wprowadziła pojęcie pamięci magazynującej, dla której dialektycznym przeciwieństwem jest pamięć funkcjonalna. Nieaktywne treści pamięci mogą stać się w przyszłości przedmiotem upamiętniania, przenikając do pamięci funkcjonalnej (A. Assmann, Przestrzenie pamięci. Formy i przemiany pamięci kulturowej, przeł. P. Przybyła, [w:] Pamięć zbiorowa i kulturowa. 
miejsc, ludzi, zdarzeń, lecz osadza się w krajobrazie, sam krajobraz czyniąc nośnikiem pamięci: to on przechowuje «wspomnienie» w postaci śladów dawnej aktywności człowieka" ${ }^{39}$.

Krajobraz konstytuuje się więc jako świadectwo życia ludzi (lokalnej społeczności, wspólnoty), którzy przez swoją aktywność i działania ukształtowali go, zawsze pozostawiając coś po sobie: zbudowany dom, posadzone drzewo, nowe opowieści. Jako przestrzeń śladów pełny jest zatem znaków poprzednich pokoleń. Trzeba jednak umieć je rozpoznać i odczytać. Bez tego krajobraz będzie niemy, pozostanie widokiem. Sztuka odczytywania znaków staje się zaś szczególnie przydatna, gdy w miejsce pamięci wkracza zapomnienie lub niepamięć. Gdy o pracy mieszkańców Wancerzowa w nieodległej i nieistniejącej już cegielni mówi się coraz mniej, wspomina coraz rzadziej; i gdy przejeżdżający przez Mstów turyści nie wiedzą, że nad rzeką znajduje się żydowski cmentarz - dziś z kilkoma jedynie macewami.

Ta umiejętność czytania śladów potrafi sprawić, że dziedzictwo kulturowe istniejące potencjalnie, przemienia się w dziedzictwo zaktualizowane, ruchliwe i czynne.

\section{Bibliografia}

\section{Opracowania}

Angutek D., Tradycje wytworzone rodzącej sięponowoczesności w Polsce, Bydgoszcz 2018.

Assmann A., Przestrzenie pamięci. Formy i przemiany pamięci kulturowej, przeł. P. Przybyła, [w:] Pamięć zbiorowa i kulturowa. Wspótczesna perspektywa niemiecka, red. M. Saryusz-Wolska, Kraków 2009.

Buczyńska-Garewicz H., Miejsca, strony, okolice. Przyczynek do fenomenologii przestrzeni, Kraków 2006.

Connerton P., How Modernity Forgets, Cambridge-New York 2009.

Connerton P., Jak spoteczeństwa pamiętaja, przeł. M. Napiórkowski, Warszawa 2012.

Frydryczak B., Krajobraz: dziedzictwo zamieszkiwane, [w:] Dziedzictwo we wspótczesnym świecie. Kultura, natura, cztowiek, red. A. Marciniak, M. Pawleta, K. Kajda, Kraków 2018.

Frydryczak B., Krajobraz. Od estetyki the pictuersque do doświadczenia topograficznego, Poznań2013.

Gaweł Ł., Szlaki dziedzictwa kulturowego. Teoria i praktyka zarządzania, Kraków 201 I.

Głowacki M., Kopacz J., Z pradziejów regionu częstochowskiego, „Ziemia Częstochowska” I974, t. IO.

Ingold T., Czasowość krajobrazu, przeł. R. Chymkowski, [w:] Antropologia pamięci. Zagadnienia i wybór tekstów, red. P. Majewski, M. Napiórkowski, Warszawa 2018.

Krupa-Ławrynowicz A., Zmiany i napięcia w krajobrazie jurajskiej wsi. Na marginesie badań w Mstowie, „Zeszyty Wiejskie” 2016, t. 22.

Wspótczesna perspektywa niemiecka, red. M. Saryusz-Wolska, Kraków 2009. Krajobraz można traktować jako rodzaj magazynu pamięci.

39 Tamże, s. IO2. 
Kubicki A., Z przesztości Mstowa. Notatki kronikarskie od średniowiecza do I939 roku, Częstochowa 201r.

Laberschek J., Średniowieczne dzieje nadwarciańskiego Mstowa, Kraków 2014.

Lowenthal D., Życie z krajobrazem i oglądanie krajobrazu, przeł. D. Stadnik, [w:] Krajobrazy. Antologia tekstów, red. B. Frydryczak, Poznań 2014.

Mstów. Miasto - klasztor - parafia na przestrzeni wieków, red. K. Łatak, Łomianki 2013.

Nora P., Między pamięcia i historią: Leslieux de Mémoire, „Tytuł roboczy: Archiwum” 2009, nr 2.

Orman K., Orman P., Wielka Wojna na Jurze. Dziatania i cmentarze wojenne z roku IgI4 na Wyżynie Krakowsko-Wieluńskiej i terenach przylegtych, Kraków 2015.

Otwarta gmina Mstów. Przewodnik turystyczny, red. J. Pleszyniak, Katowice 2020, http:// www.mstow.pl/media/2020/news-03/Przewodnik-turystyczny_Gmina-Mstow.pdf.

Ossowski S., Dzieta, t. 3: Z zagadnień psychologii spotecznej, Warszawa 1967.

Ossowski S., O ojczyźnie i narodzie, Warszawa 1984.

Ossowski S., Z zagadnień psychologii spotecznej, Warszawa 2000.

Pietrzykowski J., Hitlerowcy w powiecie czestochowskim 1939-1945, Katowice 1972.

Sochnacki A., Mstów w czasach staropolskich, [w:] Mstów. Miasto - klasztor-parafia na przestrzeni wieków, red. K. Łatak, Łomianki 2013.

Szpociński A., Miejsca pamięci (lieux de memoire), „Teksty Drugie” 2008, nr 4.

Tilley Ch., Praktykowanie krajobrazu, przeł. D. Stadnik, [w:] Krajobrazy. Antologia tekstów, red. B. Frydryczak, Poznań 2014.

Wejland A.P., Pojęcia podstawowe, [w:] Miejsca pamięci i miejsca zapomnienia. Interdyscyplinarne badania na Jurze Krakowsko-Częstochowskiej. Raportz badań, t. I: Wprowadzenie metodologiczne, red. A.P. Wejland, O. Ławrynowicz, Łódź 2016.

\section{Strony internetowe}

Oficjalna strona internetowa gminy Mstów, http://www.mstow.pl/

Śladami Przesztości po Gminie Mstów,http://www.mstow.pl/art/3939,sladami-przeszlosci-po-gminie-mstow

Streszczenie: Artykuł poświęcony jest przedsięwzięciu zrealizowanemu w 2015 r. w gminie Mstów (pow. częstochowski, woj. śląskie), polegającemu na zainstalowaniu na terenie (w krajobrazie) tej jurajskiej gminy tablic informacyjnych pod wspólnym tytułem „Śladami Przeszłości po Gminie Mstów”. Tablice, prezentujące fotografie oraz krótką notatkę dotyczącą historii danego miejsca (dziś już często nieistniejącego lub posiadającego inny charakter), ustawione zostały w pierwotnych lokalizacjach obiektów wpisujących się w lokalną historię i dziedzictwo. Twórcami projektu są Urząd Gminy, „lokalni eksperci - pasjonaci” oraz mieszkańcy. To oni nie tylko dzielili się wspomnieniami (stanowiącymi bazę do tworzenia opisów), ale również otwierali swoje domowe archiwa i udostępniali unikatowe, bo niedostępne w tzw. oficjalnych opracowaniach, fotografie. Zaproponowany etnograficzny przypis jest komentarzem do tej terenowej ekspozycji, która służyć ma m.in. celom krajoznawczym, edukacyjnym, zachowaniu pamięci o miejscach, których istnienie w społecznej świadomości i przypisywane im wartości pomagają podtrzymywać lokalną tożsamość. Pojęciem porządkującym i nadającym kontekst rozważaniom jest krajobraz rozumiany jako konstrukt kulturowy, społeczny oraz czasowy.

Słowa klucze: krajobraz, lokalna społeczność, lokalna historia, pamięć, gmina Mstów (woj. śląskie) 
Summary: The article focuses on the project carried out in 2015 in the Mstów commune (Częstochowa district, Silesian Voivodeship), consisting in the installation of information boards in the area (in the landscape) of this Jurassic commune under the common title "Śladami Przeszłości po Gminie Mstów". The boards, presenting photographs and a short note on the history of a place (today often non-existent or having a different character), were placed in the original locations of objects connected to the local history and heritage. The authors of the project are the Commune Office, "local experts - enthusiasts" and residents. It was them who not only shared their memories (for creating descriptions), but also opened their home archives and made available unique photographs, not available in the official studies. The proposed ethnographic footnote is a commentary to this field exhibition, which has a sightseeing, educational character, preserving the memory of places which existence in social consciousness and the values attributed to them help to maintain the local identity. The concept that organizes and gives context to the considerations is landscape understood as a cultural, social and time construct.

Keywords: landscape, local community, local history, memory, Mstów commune (Silesian Voivodeship)

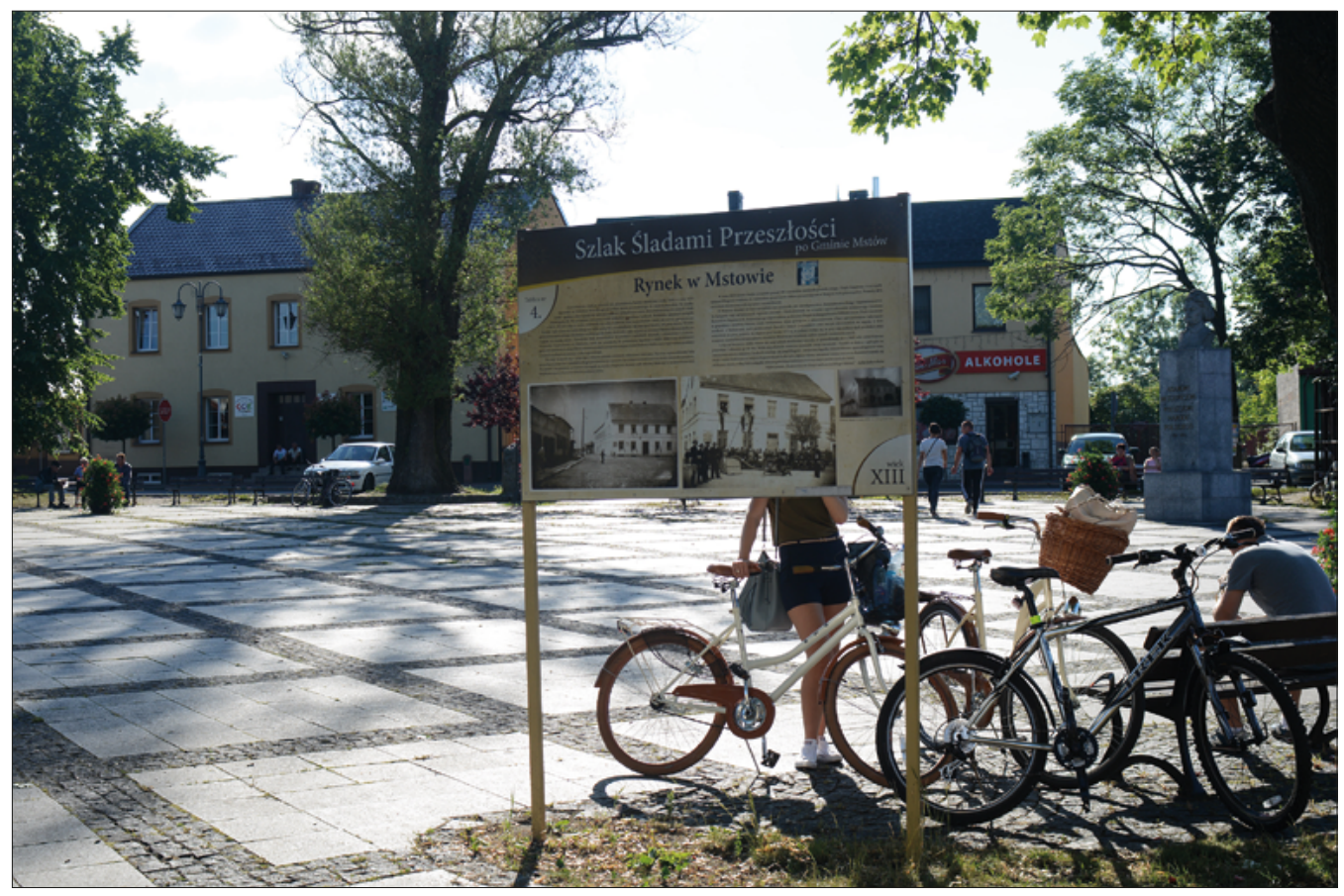

FOт. 1A, 1в Rynek w Mstowie. Obecnie pl. A. Mickiewicza, centrum dawnego założenia miejskiego Mstowa. Do I8II r. w rynku stał ratusz. W I879 r. zabudowa rynkowa spłonęła, ale uzupełniono ją do końca XIX w. Tu znajdowały się przed II wojną światową szkoła, sklepy, punkty usługowe prowadzone przez miejscowych rzemieślników. (fot. A. Krupa-Ławrynowicz 2017) 
ALEKSANDRA KRUPA-ŁAWRYNOWICZ Lokalność w krajobrazie. Etnograficzny przypis do projektu...

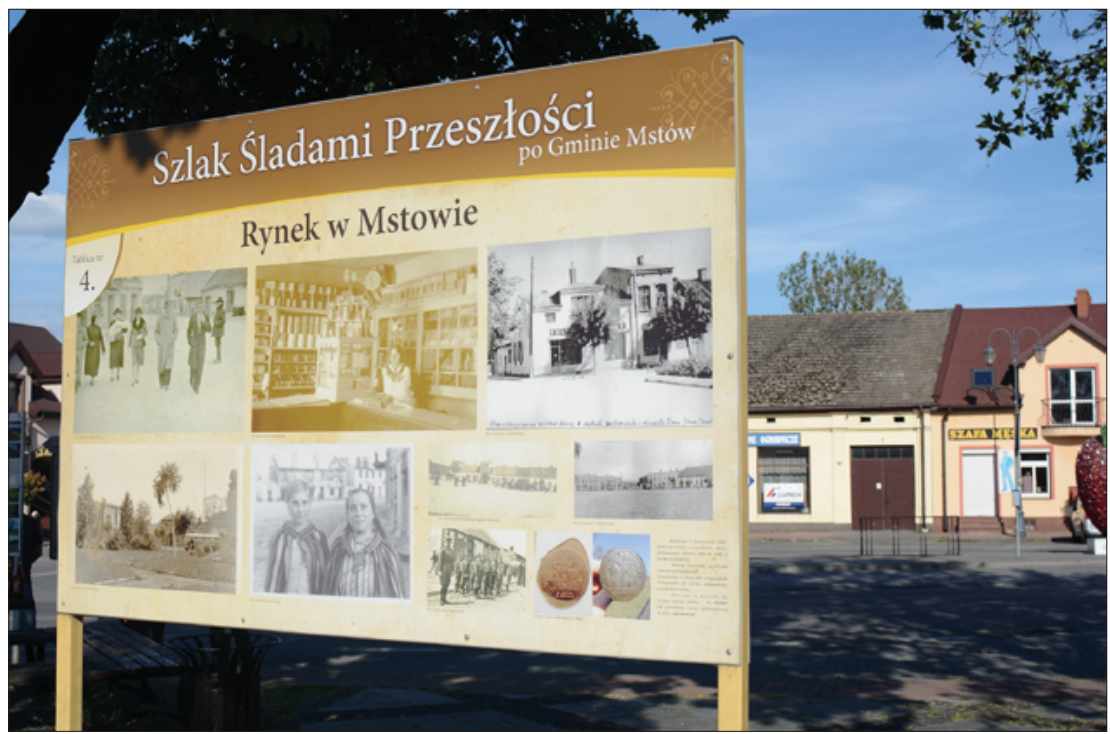

FOT. 1B

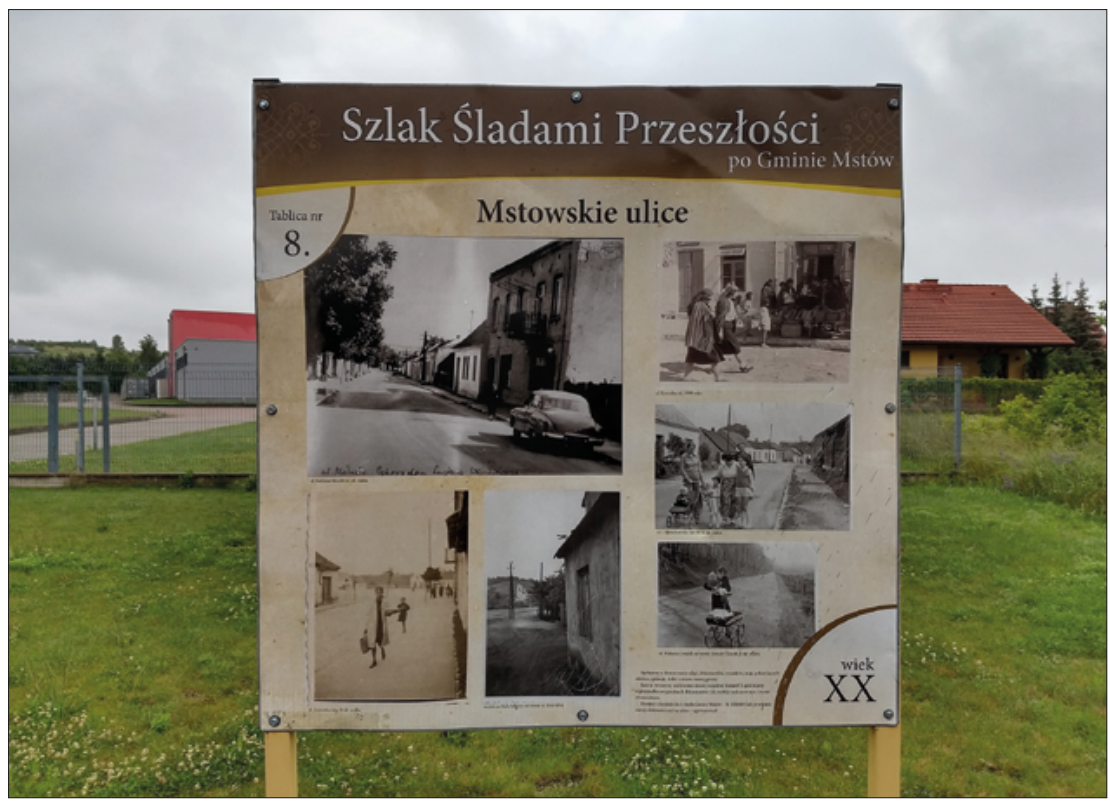

FOT. 2 Mstowskie ulice. Na fotografiach ulice: Wolności (dawniej Małuska), lata 60. XX w.; Kościelna, lata 30. Xx w.; widok na Skałę Miłości od strony ul. Kościelnej; Częstochowska, lata 60. xx w.; Wolności, lata 60. Xxw. (fot. A. Krupa-Ławrynowicz 2020) 
ALEKSANDRA KRUPA-ŁAWRYNOWICZ Lokalność w krajobrazie. Etnograficzny przypis do projektu...

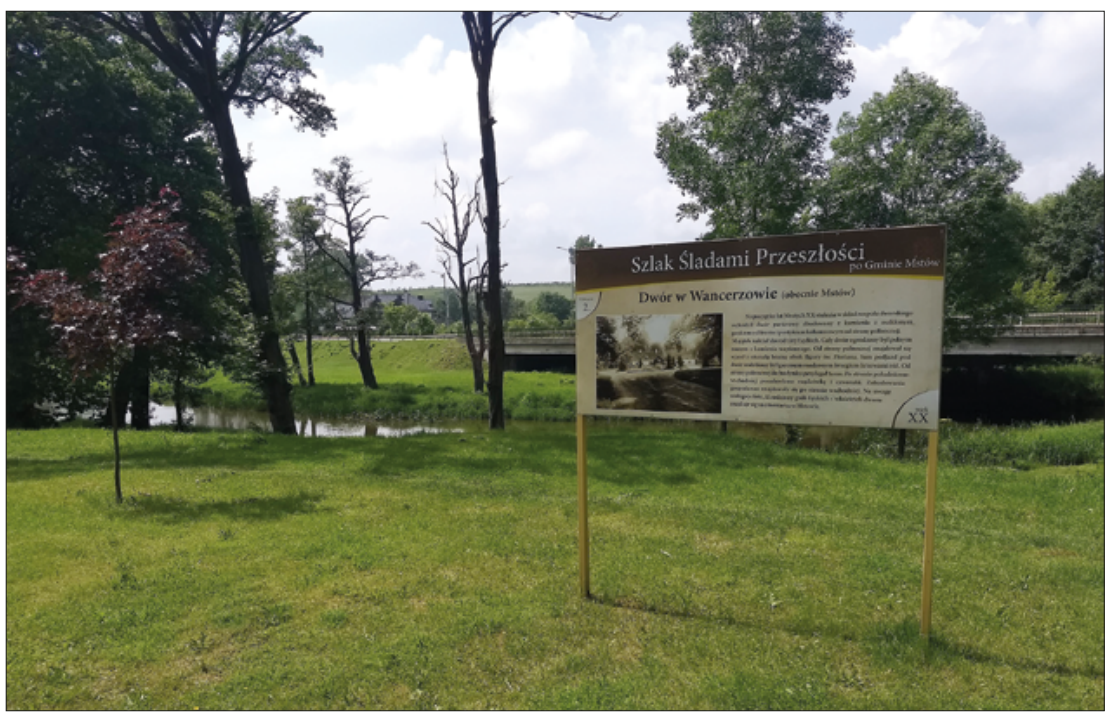

FOт. 3 Dwór w Wancerzowie (obecnie Mstów). Na początku lat 30. XX w. w skład zespołu dworskiego wchodził dwór parterowy, rządcówka, czworaki i zabudowania gospodarcze. Majątek należał do rodziny Łęckich, których grób znajduje się na cmentarzu w Mstowie. (fot. A. Krupa-Ławrynowicz 2020)

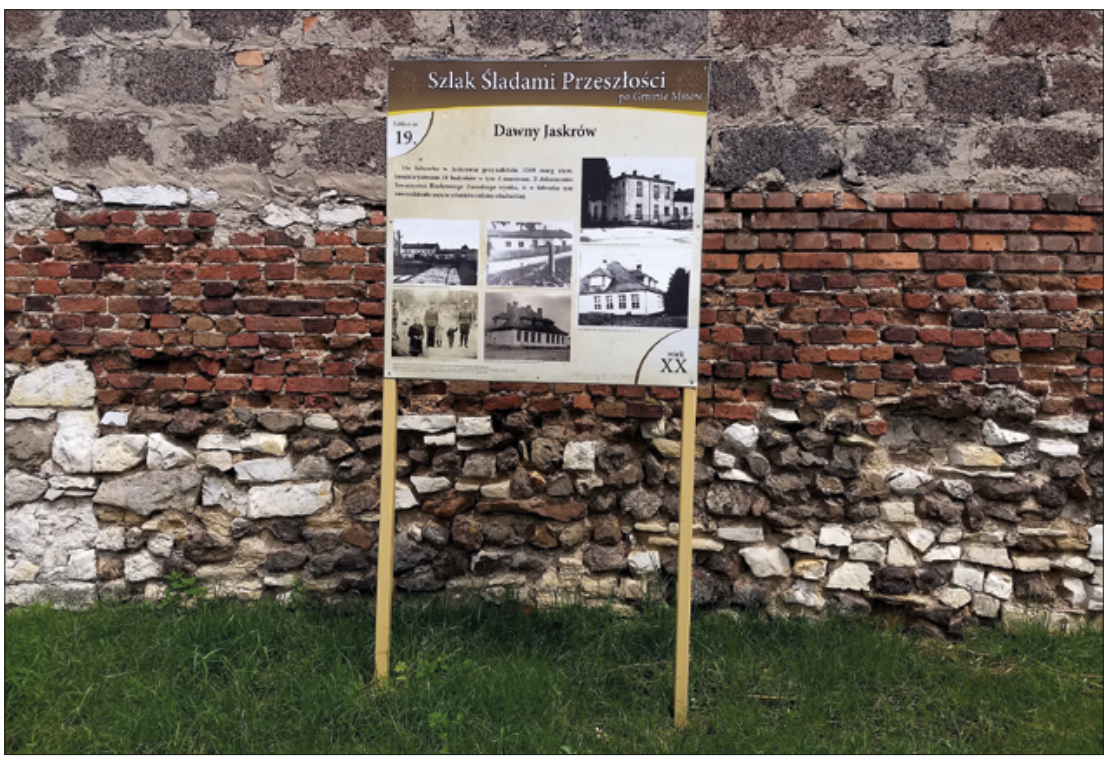

FOт. 4 Dawny Jaskrów. Do folwarku w Jaskrowie przynależało ponad 1200 mórg ziemi, ro budynków, w tym 4 murowane. (fot. A. Krupa-Ławrynowicz 2020) 
ALEKSANDRA KRUPA-ŁAWRYNOWICZ Lokalność w krajobrazie. Etnograficzny przypis do projektu...

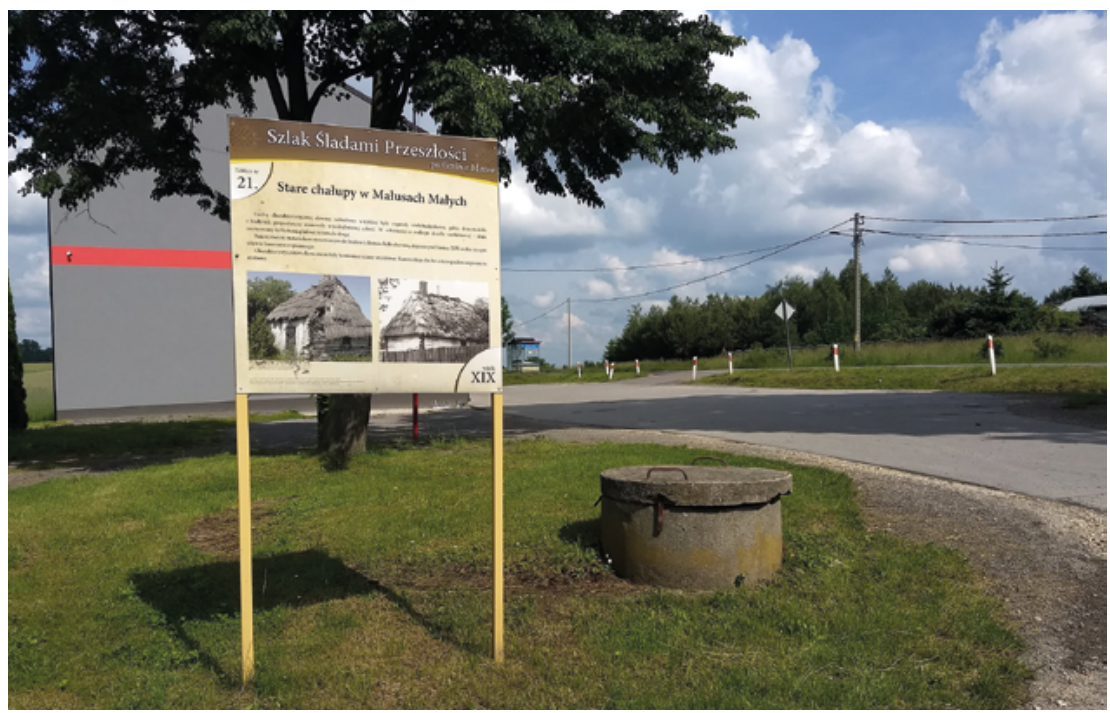

FOт. 5 Stare chałupy w Małusach Małych. Zagrody wielobudynkowe, najczęściej drewniane, pod koniec XIX w. budowane z miejscowego kamienia wapiennego. (fot. A. Krupa-Ławrynowicz 2020)

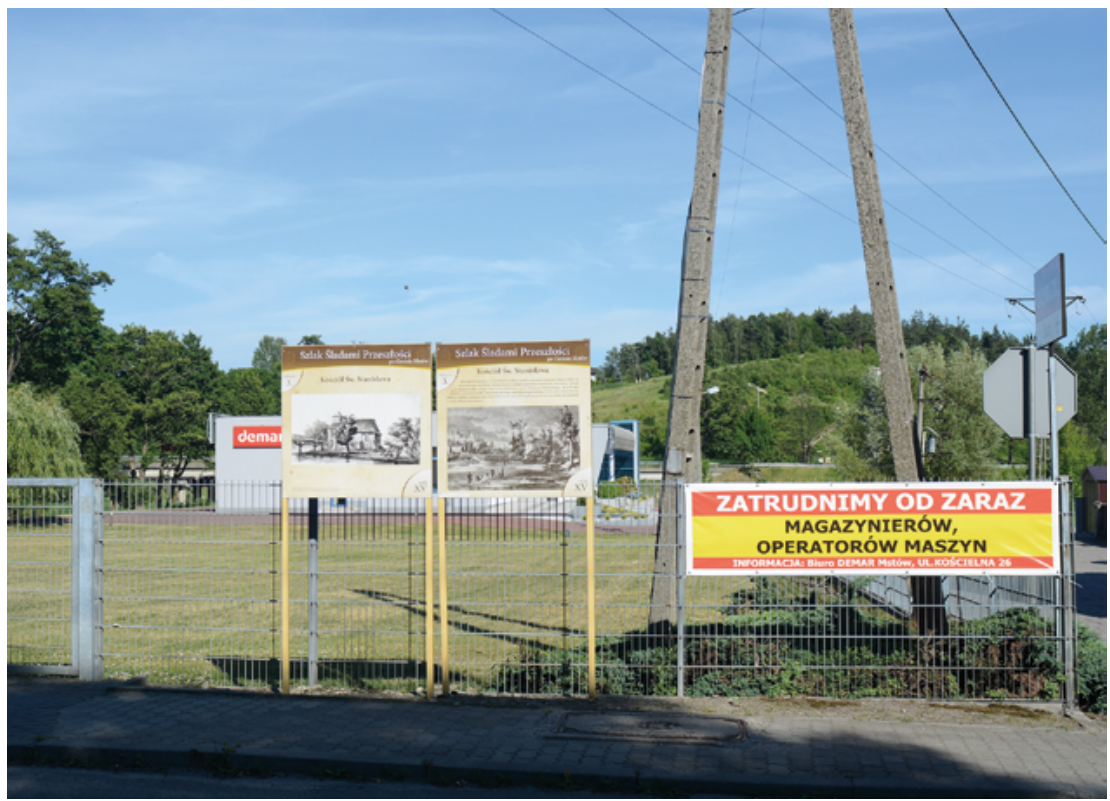

FOT. 6 Kościół św. Stanisława. Nieistniejący kościół w Mstowie, wzniesiony w XVw. na prawym brzegu rzeki Warty. Dwa razy spłonął - na początku XVIIIw. i w drugiej pol. XIX w. (fot. A. Krupa-Ławrynowicz 2017) 
ALEKSANDRA KRUPA-ŁAWRYNOWICZ Lokalność w krajobrazie. Etnograficzny przypis do projektu...

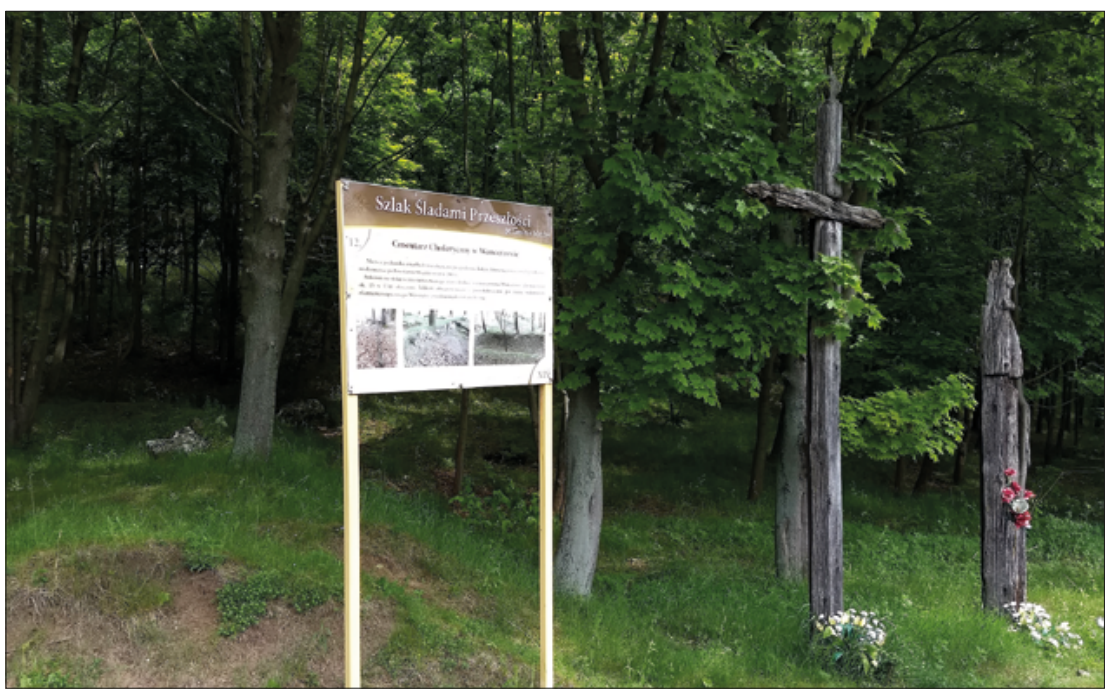

FOт. 7 Cmentarz choleryczny w Wancerzowie. (fot. A. Krupa-Ławrynowicz 2020)

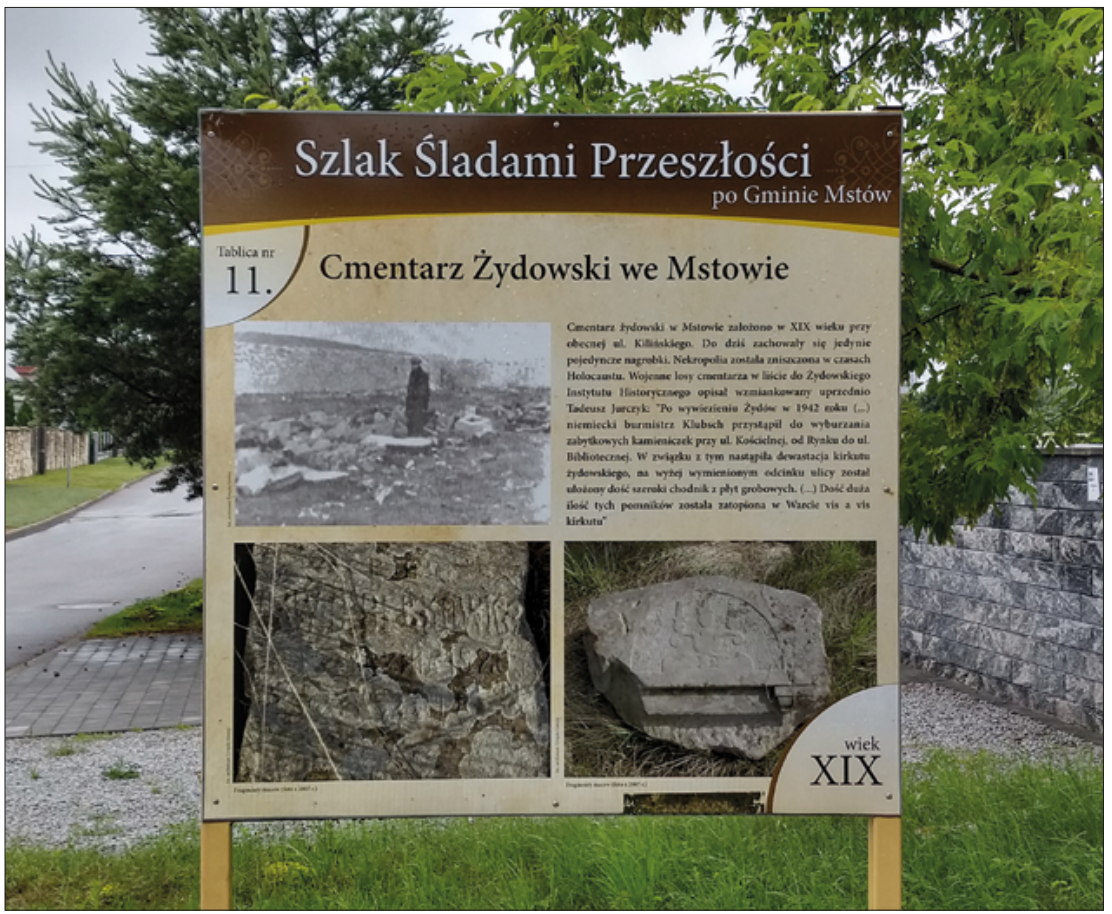

FOT. 8 Cmentarz żydowski w Mstowie. Założony w XIX w., do dziś zachowały się jedynie pojedyncze nagrobki. (fot. A. Krupa-Ławrynowicz 2020) 
ALEKSANDRA KRUPA-ŁAWRYNOWICZ Lokalność w krajobrazie. Etnograficzny przypis do projektu...

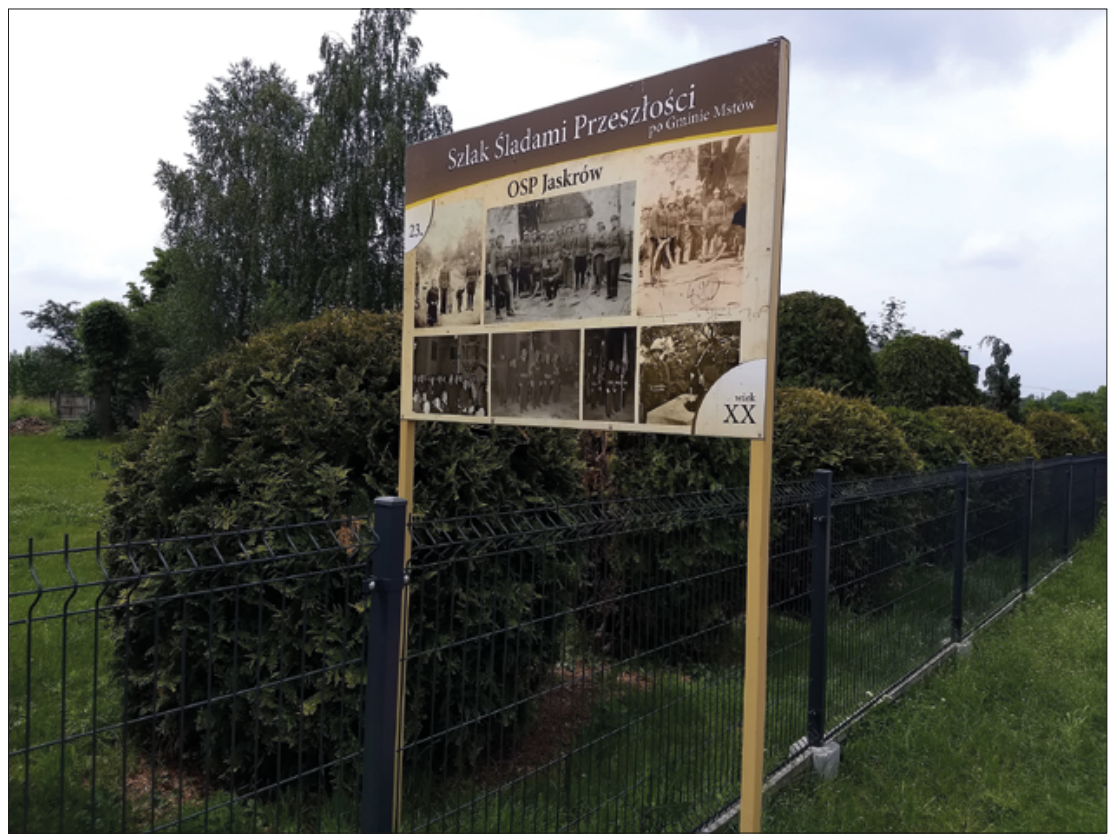

FOT. 9 OSP Jaskrów. (fot. A. Krupa-Ławrynowicz 2020)

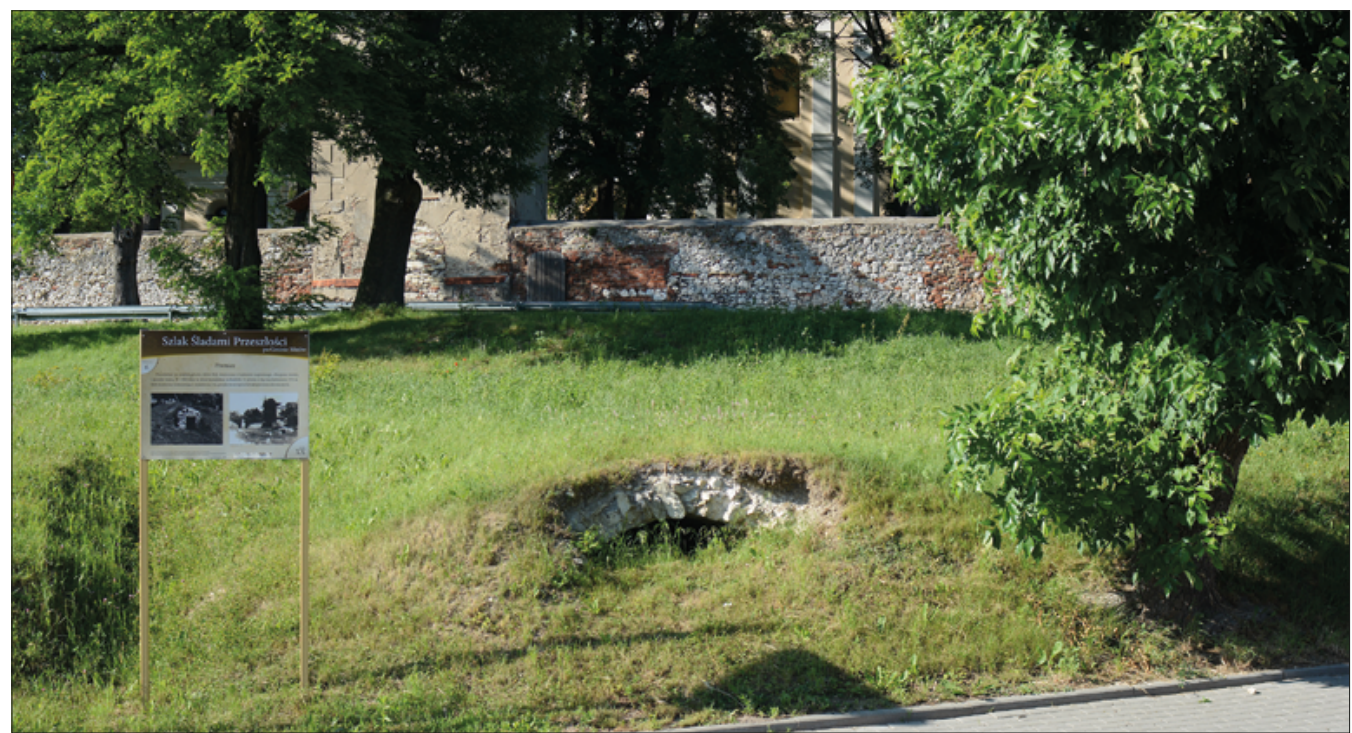

FOT. 10 Piwnice. Pozostałość po zespole piwnic wolnostojących, zbudowanych z kamienia wapiennego, obsypanych ziemią i porosłych trawą.

(fot. A. Krupa-Ławrynowicz 2017) 
ALEKSANDRA KRUPA-ŁAWRYNOWICZ Lokalność w krajobrazie. Etnograficzny przypis do projektu...

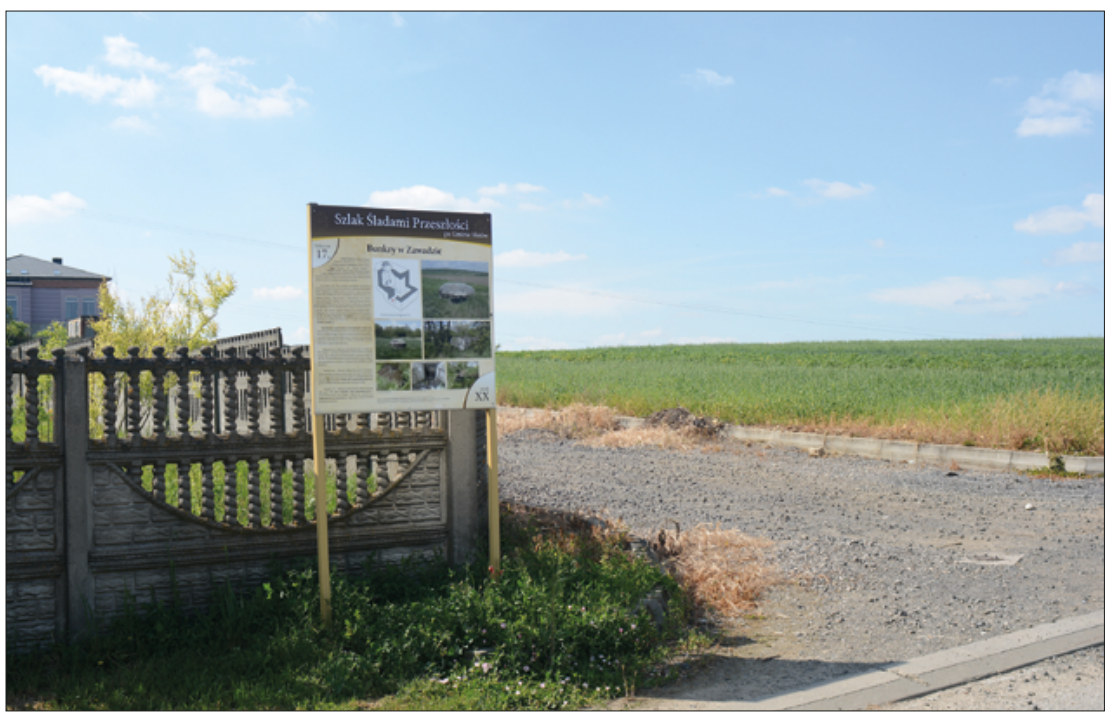

FОт. 11 Bunkry w Zawadzie. Zespół bunkrów z czasów II wojny światowej, zbudowanych w 1944 r. na rozległym terenie jako element planowanej niemieckiej linii obrony przed natarciem ze wschodu. Największy z nich to schron Rigelbau 70I, obecnie zasypany, z widoczną górną częścią; pozostałe obiekty zwane kochbunkrami, porośnięte trawą. (fot. A. Krupa-Ławrynowicz 2017)

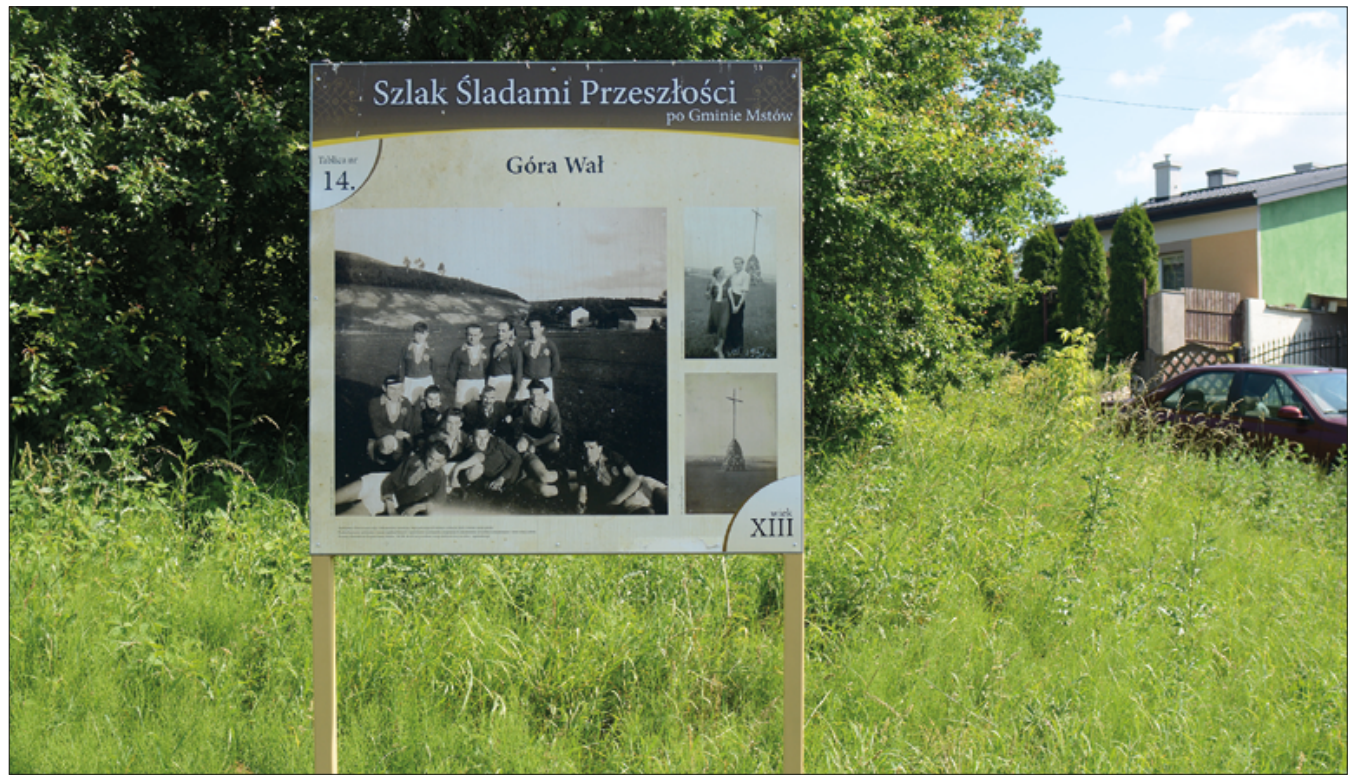

Fот. 12 Góra Wał. (fot. A. Krupa-Ławrynowicz 2017) 